\title{
The Effect of Family Room Lighting on Incidence of Positive AFB Lung TB in Serdang Bedagai Regency
}

\author{
Ika Dewi Purba ${ }^{1}$, Rahayu Lubis $^{2}$, Nurmaini $^{2}$ \\ ${ }^{1}$ Master Student in Universitas Sumatera Utara, Medan, Indonesia \\ ${ }^{2}$ Lecturer in Universitas Sumatera Utara, Medan, Indonesia \\ Email: ikadewi280781@gmail.com
}

\begin{abstract}
:
The aims of the study is to find out the effect of lighting in family room. This type of research uses observational analytic studies with case-control study designs. The result of the study shows that there is the effect of lighting in the family room $(p=0.010, O R=4.125,95 \% C I=1,473-11,555)$, lighting in the room $(p=0.009, O R=3.167,95 \% C I=1,398-7,174)$ with the incidence of pulmonary $T B$, while the incidence of pulmonary $T B$ disease, whereas occupancy density had no effect ( $p=0.263)$. The result of multivariate analysis showed that lighting in the family room had the strongest influence with TB disease ( $p=0.001$ and Exp (B) of 24.560).
\end{abstract}

Keywords:

The effect of lighting; family room; lung $T B$

\section{Introduction}

In North Sumatra Province, pulmonary TB is an old disease that still persists. The number of new cases found in pulmonary TB patients in North Sumatra in 2017 was 104.3 per 100,000 population, while the highest number of new cases was in the city of Medan with 5206 people, followed by Deli Serdang Regency2090 people, then Langkat 850 people, Simalungun 846 people, Madina 822 people, Asahan 638 people, Tapteng 624 people, and Serdang as many as 542 positive people (Provincial Health Office, North Sumatra, 2017).

The working area of Serdang Bedagai Regency has 20 public health centre located in urban and rural areas with different population characteristics. Serdang Bedagai Regency is also an endemic area of pulmonary TB, namely in 2016 the number of 484 cases, in 2017 there was an increase in cases to 542 cases and in 2018 as many as 820 cases (Department of healty of Serdang Bedagai Regency, 2017).

TB is often considered a disease of witchcraft, poisons, witchcraft, curses and even hereditary diseases. Treatment program activities in the affected community have not been carried out optimally. Sufferers also appear to be ignorant of the effects of incomplete treatment concepts. Changes in behavior in the community in breaking the chain of transmission of the disease also still do not support this program. Meanwhile the prevention program carried out by the relevant agencies to reduce the number of new pulmonary TB patients also appears to have not been implemented. Implementation of the program according to the community does not involve the community and community leaders who are considered sufficient to contribute to helping the achievement of the program. In fact, if seen from the condition of this area, it still adheres to a fairly strong understanding of the figures in the community (Ismail 2019).

Based on the initial survey in Serdang Bedagai regency, the number of pulmonary TB in 2018 was 820 people. Of the highest number of CDRs in 2018 in rural areas such as the 
working area of the Bandar khalifah public health centre at 41 percent, and there were 49 cases in the subsequent work areas at the Silinda public health centre and Tanjung Beringin at 35 percent with 14 cases and 62 cases, the Sipispis public health centre working area with 32 percent with 49 cases, and Kotarih Health Center as much as 26 percent with 10 cases, while in urban areas such as the work area of the public health centre Desa Pon and Perbaungan as much as 28 percent and 25 percent with a number of 59 and 82 cases (Serdang Bedagai Regency Health Office, 2018).

\section{Review of Literature}

\subsection{Lung Tuberculosis}

Tuberklulosis is a direct infectious disease caused by TB bacteria, namely Mycobacterium tuberculosis, although it can attack almost all other organs of the body, but TB bacteria more often attack the lung organs (80-85 percent) (MOH, 2008). Pulmonary TB disease is a chronic infection caused by Mycobacterium tuberculosis which typically forms germ granules in the lungs causing necrosis or tissue (Achmadi, 2014).

Lung TB is an annual disease, even a lifetime. Patients who are sick without treatment after five years, 50 percent of people with pulmonary TB will die, 25 percent healthy with good body defense and another 25 percent become chronic and infectious (Jusuf, 2010). Pulmonary TB bacteria called Mycobacterium tuberculosis rod-shaped length 1-4 microns long and 0.3-0.6 microns thick, resistant to acidic staining or Acid Resistant Bacteria (BTA). When BTA is found in the sputum of a person who often coughs, then that person is diagnosed as an active pulmonary TB patient and is very dangerous because it has very dangerous potential (Achmadi, 2014). TB bacteria will die quickly with direct sunlight, but can survive several hours in dark and damp places (Achmadi, 2014)

\subsection{Factors that Influence Lung TB Disease}

Behavior is what is done by living things, whether directly or indirectly observed human behavior can be seen from three aspects, namely: physical, psychological and social aspects which are in detail a reflection of various mental fluctuations such as knowledge, motivation, perception, attitude and etc., which are determined and influenced by factors of experience, beliefs, physical and socio-cultural facilities of the community. Even internal activities such as thinking, perceiving and emotions are also human behavior.

In line with behavioral constraints according to Skinner, health behavior is basically a person's response (organism) to a stimulus related to illness and illness, the health care system, food, and the environment. Health efforts undertaken to realize one's health are carried out with four different approaches namely maintenance and health promotion, prevention of disease, healing of the disease and recovery of health.

Human responses or reactions can be divided into two groups, namely those that are passive and active. Passive (knowledge, perception and attitude), active (real action or practice). Behavior towards health services is one's response to health services both modern health services and traditional health services. This behavior concerns the response to service facilities, service methods, health workers, and medicines, which is manifested in the knowledge, perceptions, attitudes and users of facilities, officers, and medicines. A person's behavior is influenced by several factors originating from within and from outside the individual itself. These factors include; central nervous system, perception, motivation, emotion, learning process, environment and so on (Notoatmodjo, 2012). 
Lawrence Green (1980) in Notoatmodjo (2012) analyzes human behavior from the level of health, health of a person or community influenced by 2 main factors, namely:

a. Behavioral factors

b. Non-behavioral factors (non-behavioral causes)

Furthermore, behavioral factors are influenced by three main factors, namely predisposing factors, enabling factors, and reinforcing factors

\subsection{Spatial and Occupancy Density.}

Each house must have a room that matches its function. Determination of the shape, size and number of rooms needs to pay attention to the standard number of rooms. Because the residence must have a room that is a bedroom, guest room, dining room, kitchen, bathroom, and toilet.

According Achmadi (2014) Density is one of the pre-requisite for the disease transmission process. The more dense, the transfer of diseases, especially diseases through the air, will be easier and faster. Therefore density in residential homes is a variable that plays a role in the incidence of pulmonary TB.

Density is a comparison between the floor area of a house and the number of family members in a single residence. For this reason the Ministry of Health has made regulations on healthy housing. The requirements for occupancy density for all ordinary housing are expressed in $\mathrm{m}^{2}$ per person. The minimum area per person is very relative, depending on the quality of the building and facilities available. For simple housing a minimum of $10 \mathrm{~m}^{2}$ per person. For bedrooms in need a minimum floor area of $3 \mathrm{~m}^{2}$ per person. Bedrooms should not be inhabited $\geq 2$ people except for husband and wife under two years. The distance between one beds with the other is $90 \mathrm{~cm}$. If there are family members who suffer from TB disease, they should not sleep with other family members Ministry of Health of the Republic of Indonesia (1999).

The density of the residents in one house will give effect to the occupants. The area of the house that is not proportional to the number of inhabitants will cause overcrowded. This is unhealthy because in addition to causing a lack of oxygen consumption, also if one family member suffers from an infectious disease especially pulmonary TB it will be easily transmitted to other family members, because an average sufferer can transmit it to two to three people in his house $(\mathrm{MOH}, 2002)$.

\subsection{Lighting}

According to Achmadi (2014) A healthy home requires sufficient light, not less and not too much, especially natural light in the form of sunlight which contains, among others, ultraviolet (Achmadi, 2008). Lack of light entering the room of the house, especially sunlight besides being less comfortable, is also a good medium or place for living and developing germs. Conversely too much light in the house will cause glare, and ultimately can damage the eyes. Muslimah (2018) states that there is a significant relationship between natural lighting with the presence of mycobacterium tuberculosis. 


\section{Research Method}

This type of research uses observational analytic studies with case-control study designs, because this research is a rare case, and the latency is long, the research costs are relatively cheap but the results are quickly known and can identify risk factors at once. This research was carried out in Serdang Bedagai regency with the consideration that this region is a positive endemic area of AFB smear TB compared to other regions. This research was conducted in December 2018 until September 2019.

\section{Discussion}

Based on the analysis of the effect of lighting in the family room on the incidence of positive pulmonary TB disease, it is known that the proportion of respondents who have less lighting in the family room in the case group (36.0\%) is higher than in the control group $(12.0 \%)$. The results of statistical tests with chi-square showed that there was a significant effect between lighting in the family room with the incidence of Positive AFB Lung TB ( $\mathrm{p}=$ $0.01)$.

The results of the cross tabulation analysis obtained an Odds ratio of 4.125 with a Confidence Interval of 1.473-11.555 meaning that the Odds of Positive BTA Lung TB incidence in the group of respondents who had less lighting in the family room was 4.125 times compared to respondents who did not suffer from Pulmonary TB. The results of these cross tabulations can be seen in Table 1 below:

Table 1. Cross Tabulation of Lighting in the Family Room with Positive BTA Lung TB in the Serdang Bedagai Regency in 2019

\begin{tabular}{|c|c|c|c|c|c|c|}
\hline \multirow{3}{*}{$\begin{array}{l}\text { Lighting in the } \\
\text { family room }\end{array}$} & \multirow{2}{*}{\multicolumn{2}{|c|}{ Case }} & & & \multirow[t]{2}{*}{$P$} & \multirow{2}{*}{$\begin{array}{c}\text { OR } \\
(95 \% \mathrm{CI})\end{array}$} \\
\hline & & & $\begin{array}{c}\text { Contro } \\
1\end{array}$ & & & \\
\hline & $\mathrm{f}$ & $\%$ & $\overline{\mathrm{f}}$ & $\%$ & & \\
\hline \multirow{2}{*}{$\begin{array}{c}\text { Less } \\
\text { Enough }\end{array}$} & 18 & 36,0 & 6 & 12,0 & 0,010 & 4,125 \\
\hline & 32 & 64,0 & 44 & 88,0 & & $(1,473-11,555)$ \\
\hline Total & 50 & 100 & 50 & 100 & & \\
\hline
\end{tabular}

Based on the results of the analysis of the influence of lighting in the room with the incidence of positive pulmonary TB disease, it is known that the proportion of respondents who have less lighting in the room in the case group $(62.0 \%)$ is higher than in the control group $(34.0 \%)$. Statistical test results with chi-square showed that there was a significant effect between lighting in the family room with the incidence of Positive AFB Lung TB disease ( $\mathrm{p}=$ 0.009).

The results of the cross tabulation analysis obtained an Odds ratio of 3.167 with a Confidence Interval of 1.398-7.174, meaning that the Odds of Positive BTA Lung TB incidence in the group of respondents who had less lighting in the room was 3.167 times compared to respondents who did not suffer from Pulmonary TB. The results of these cross tabulations can be seen in Table 2 below: 
Table 2. Cross Tabulation of Lighting in a Room with a Positive BTA Lung TB in the Serdang Bedagai Regency in 2019

\begin{tabular}{|c|c|c|c|c|c|c|}
\hline \multirow[t]{4}{*}{$\begin{array}{c}\text { Lighting in the } \\
\text { room }\end{array}$} & & & & & \multirow[t]{4}{*}{$P$} & \multirow[t]{4}{*}{$\begin{array}{c}\text { OR } \\
(95 \% \mathrm{CI})\end{array}$} \\
\hline & \multirow{2}{*}{\multicolumn{2}{|c|}{ Case }} & Contro & & & \\
\hline & & & 1 & & & \\
\hline & $\mathrm{f}$ & $\%$ & $f$ & $\%$ & & \\
\hline Less & 31 & 62,0 & 17 & 34,0 & 0,009 & 3,167 \\
\hline Enough & 19 & 38,0 & 33 & 66,0 & & $(1,398-7,174)$ \\
\hline Total & 50 & 100 & 50 & 100 & & \\
\hline
\end{tabular}

Multivariate analysis was conducted to analyze the effect of independent variables (respondent's age, economic status, level of education, sputum habits, cough habit, window opening habits, smoking habits, contact history, occupancy density, lighting in the family room, and lighting in the room) with the dependent variable (Positive BTA Lung TB incidence) in Serdang Bedagai Regency Work Area in 2019. Multivariate analysis uses multiple logistic regression analysis with the Enter method. Before conducting a multivariate analysis, the selection of variables as candidates for the multivariate model is first performed.

Variables that are multivariate candidates are independent variables with a value of $\mathrm{p}$ $<0.25$ in the bivariate analysis. In Table 3 it follows that from the 12 variables in this study, there are eight variables that meet the candidate variables in the multivariate test so that these variables are included in the regression model. For more details, see Table 3 below:

Table 3. Selection of Model Candidates for Multivariate Modeling Phase.

\begin{tabular}{clcl}
\hline No & \multicolumn{1}{c}{ Variable } & \multicolumn{1}{c}{$P$} & \multicolumn{1}{c}{$95 \%$ CI } \\
\hline 1. & Lighting in living room & $0,010^{*}$ & $1,473-11,555$ \\
2. & Lighting in bad room & $0,009^{*}$ & $1,398-7,174$ \\
\hline
\end{tabular}

Further multivariate analysis was performed using multiple logistic regression tests at $\alpha$ $=0.05$. The results of multivariate analysis can be seen in the following Table 4 .

Table 4. Multiple Logistic Regression Test Results for 8 Variables with p value $<0.25$ to see which variable most influential on the incidence of Positive AFB Pulmonary TB in Serdang Bedagai Regency Working Area in 2019

No

$$
\text { Variable }
$$

$$
\text { Score P Score B Exp B }
$$

Step I Lighting in living room

$\begin{array}{llll}0,001 & 3,132 & 22,930 & 3,626-144,996 \\ 0,003 & 1,936 & 6,928 & 1,962-24,469\end{array}$

Lighting in bad room

$1,962-24,469$

Step 2 Lighting in living room

$\begin{array}{llll}0,001 & 3,157 & 23,498 & 3,711-138,790 \\ 0,003 & 1,929 & 6,880 & 1,953-24,228\end{array}$

Step 3 Lighting in living room

$\begin{array}{llll}0,000 & 3,448 & 31,439 & 5,023-96,783 \\ 0,002 & 1,907 & 6,731 & 1,987-22,809\end{array}$

Lighting in bad room

0,002

$1,907 \quad 6,731$

$1,987-22,809$

Step 4 Lighting in living room

$0,000 \quad 3,201 \quad 24,560 \quad 4,600-71,117$

Lighting in bad room

0,004

$1,693 \quad 5,438$

$1,726-17,132$

$*=$ issued in phases for $\mathrm{p}$ values greater than 0.05 to be tested for the next step. 
The table above shows that the results of the first stage of the test using the enter method are removing one by one and starting from the largest $\mathrm{p}$ value. The age variable of the respondent with a value of $\mathrm{p}=0.718$ is the variable that has the largest value of $\mathrm{p}$ so that it will be issued for the next test phase. While the third stage test is the contact history variable with a value of $\mathrm{p}=0.070$ is the variable with the largest $\mathrm{p}$ value so that it will be issued for the next test phase.

Based on the table above, it can be seen that five variables that have a significant relationship $(\mathrm{p}<0.005)$ until the final stage of multivariate analysis, namely the lighting variable in the family room have the strongest influence on the incidence of Positive AFB Lung TB in the Work Area of Serdang Bedagai Regency in 2019 with a value of $p=0.001$ with and $\operatorname{Exp}(\mathrm{B})$ of 31.439 means that respondents who have less lighting in the family room, have a risk of 31.439 times more likely to experience the incidence of Positive AFB Lung TB. Percentage Correct value obtained by $81.0 \%$, which means the lighting variable in the family room explains its effect on the incidence of positive pulmonary TB disease by $81.0 \%$, while the remaining $19.0 \%$ is influenced by other factors not included in this research variable.

Based on the results of the analysis, the regression equation can be written as follows:

$$
\begin{aligned}
& \mathrm{P}=\frac{1+\mathrm{e}^{-(\mathrm{a}+\mathrm{b} 1 \mathrm{x} 1+\mathrm{b} 2 \times 2+\ldots . . \mathrm{bixi})}}{\mathrm{P}}=\frac{1}{1+\mathrm{e}^{(-15,585+(1,711) \text { sta.ekonomi+(1,721)b.dahak }+(1,753) \text { merokok }+(3,201) \mathrm{c} . \text { keluarga }+(1,693) \mathrm{c} . \text { kamar }}} \\
& \mathrm{P}=\frac{1}{1+2,718^{(25,664)}}
\end{aligned}
$$

With the regression equation model obtained, then we get a big picture of the probability of the occurrence of Positive AFB LOW TB in the Serdang Bedagai Regency in 2019, i.e. if the respondent has a family room and sufficient lighting, then the probability value has a positive TB LOW of $19.0 \%$.

Furthermore, based on the results of the regression analysis above, it can also be explained that the factors associated with the incidence of Positive AFB Lung TB in the Serdang Bedagai Regency in 2019 are lack of family room lighting factors which are the dominant variables causing the positive AFB Lung TB in Serdang Bedagai Regency Working Area in 2019.

Characteristics of respondents based on lighting in the family room, using the criteria for under-lighting and adequate lighting. Based on univariate analysis, it was found that in the case and control group more respondents had adequate lighting in the family room as many as 32 people $(64.0 \%)$ and 44 people $(88,0 \%)$ compared to respondents having less lighting in the family room.

In the study of Ismiyanti, et al (2018) in Banyuwangi, it was stated that there was a significant relationship between lighting in the family room with an OR value of 4.571 (CI = 1.182 - 17,678) and new cases of positive pulmonary TB. 
Even a small house has windows that open it every morning. Absence of window or window function, dark and damp can disrupt the lighting system, regulating air temperature and changing the fresh air in the house. Moreover, the condition of the house is not entered direct sunlight, can be a breeding ground for the Mycobacterium tuberculosis bacteria in the room and can cause these bacteria to survive longer.

Characteristics of respondents based on lighting in the room, in the group of cases more respondents had less lighting in the room as many as 31 people $(62.0 \%)$ compared to respondents having sufficient lighting in the room. Whereas in the control group there were more respondents who had sufficient lighting in the rooms as many as 33 people $(66.0 \%)$ compared to respondents who had less lighting in the room.

The lack of lighting conditions is due to the lack of ventilation in the respondent's house such as windows, doors and vents so that the sun cannot directly enter the house. Besides the close distance of the house and even close to make the window less so that the light entering the house is inadequate. There are some houses that have windows but have never been opened, on the grounds that the house was abandoned because of work and influenced by the security of the house for fear of theft.

The results of this study are in line with Suarni's (2017) study in Pancoran Mas SubRegency, Depok City, which concludes that lighting that does not meet the risk of pulmonary TB risk is 9.1 times compared to houses that have qualified lighting. Likewise with the results of Darwel's study (2012) which showed that respondents who had houses with lighting that did not meet the requirements were at risk of developing pulmonary TB by 1,564 times compared to respondents who had houses with lighting that were eligible.

Based on the lighting in the room, in the case and control group more respondents had adequate lighting, namely 32 people $(64.0 \%)$ and 44 people $(88.0 \%)$. The results of the statistical test with chi-square showed that there was a significant effect between lighting in the family analysis results obtained an Odds ratio of 4.125 with a Confidence Interval of 1.47311.555 meaning that respondents who have less lighting in risky living rooms or have a 4.125 times greater chance of developing $\mathrm{AFB}$ positive pulmonary $\mathrm{TB}$ disease compared to respondents who have adequate lighting.

Even a small house has windows that open it every morning. Absence of window or window function, dark and damp can disrupt the lighting system, regulating air temperature and changing the fresh air in the house. Moreover, the condition of the house is not entered direct sunlight, can be a breeding ground for the Mycobacterium tuberculosis bacteria in the room and can cause these bacteria to survive longer.

Based on the lighting in the room, in the case group more respondents had less lighting in the room as many as 31 people $(62.0 \%)$ compared to the respondents having sufficient lighting in the room. Whereas in the control group there were more respondents who had sufficient lighting in the rooms as many as 33 people $(66.0 \%)$ compared to respondents who had less lighting in the room.

Statistical test results with chi-square showed that there was a significant effect between lighting in the family room with the incidence of Positive AFB Lung TB disease ( $\mathrm{p}=$ 0.009). The results of the cross tabulation analysis obtained an Odds ratio of 3.167 with a Confidence Interval of 1.398-7.174, meaning that respondents who have less lighting in a 
room at risk or have a 3.167 times greater chance of developing AFB positive pulmonary TB disease compared to respondents who have adequate lighting.

The lack of lighting conditions is due to the lack of ventilation in the respondent's house such as windows, doors and vents so that the sun cannot directly enter the house. Besides the close distance of the house and even close to make the window less so that the light entering the house is inadequate. There are some houses that have windows but have never been opened, on the grounds that the house was abandoned because of work and influenced by the security of the house for fear of theft.

The results of this study are in line with Suarni's (2017) study in Pancoran Mas SubRegency, Depok City, which concludes that lighting that does not meet the risk of pulmonary TB risk is 9.1 times compared to houses that have qualified lighting. Likewise with the results of Darwel's study (2012) which showed that respondents who had houses with lighting that did not meet the requirements were at risk of developing pulmonary TB by 1,564 times compared to respondents who had houses with lighting that were eligible.

Research conducted by Mahpudin (2016) also found that those who had a lighting system that did not meet the requirements were likely to suffer tuberculosis 1.82 times compared to those who had an adequate lighting system. Houses that do not enter the sun have the risk of suffering from pulmonary TB 3-7 times compared with homes that enter the sun (Fatimah, 2019).

A healthy home requires adequate light, not less and not too much, especially natural light in the form of sunlight which contains, among others, ultraviolet (Achmadi, 2015). Data in 1993 reported that to get $90 \%$ of clean air from bacterial contamination requires 40 times air exchange per hour. Therefore, if the room is entered by sunlight and good air circulation, the risk of transmission between residents can be reduced (Widoyono, 2008). Therefore it is suggested to respondents to open their doors and windows every morning when it is working, so that sunlight enters the house.

\section{Conclusion}

Characteristics of respondents based on the age of 15-49 years as many as 28 people (56 percent) and age over 50 years as many as 22 people (44 percent), Based on economic status $<\mathrm{UMP}$ as many as 30 people ( 60 percent), $\geq \mathrm{UMP}$ of 20 people (40 percent). Based on the low education level of 35 people (70 percent) and higher education of 15 people (30 percent), based on low knowledge of 28 people (56 percent), high knowledge of 22 people (44 percent).

There is the effect of lighting in the family room $(\mathrm{p}=0.010$, OR $=4.125,95 \% \mathrm{CI}=$ 1,473 - 11,555), lighting in the room $(p=0.009$, OR $=3.167,95 \% \mathrm{CI}=1,398-7,174)$ with the incidence of pulmonary TB, while the incidence of pulmonary TB disease, whereas occupancy density had no effect $(\mathrm{p}=0.263)$. The results of multivariate analysis showed that lighting in the family room had the strongest influence with TB disease $(p=0.001$ and Exp (B) of 24.560). 


\section{References}

Achmadi, U.F, ( 2014). Manajemen Penyakit Berbasis Wilayah. Jakarta: Penerbit UI Press.

Aditama, Y, T.(2006). Tuberkulosis Paru, Diagnosis, Terapi dan Masalabnya. Edisi 4. Jakarta: IDI

Amalaguswan.,Junai, Fachlevy.,F. (2017). Analisis Faktor Risiko Kejadian Penyakit TB Paru Di Wilayah Kerja public healt centrePunvatu Kota Kendari Tabun 2017. Fakultas Kesehatan Masyarakat Universitas Halu Oleo.

Apriyani., Mujianto.,E., Habibi.,M. (2018). Pengaruh Pencabayaan dan Riwayat Merokok Terhadap Kejadian Penyakit Tuberkulosis Di Wilayah Kerja UPT public healt centreTemindung Kota Samarinda. Fakultas Kesehatan Masyarakat Universitas Widya Gama Mahakam.

Fahmi, I., (2019). Southern Tapanuli Society Perception of Pulmonary TB Health and Diseases. Budapest International Research in Exact Sciences (BirEx) Journal. 95-105

Hudoyo, A., (2008). Tuberkulosis Mudah Diobati. Jakarta: Balai Penerbit FKUI.Jakarta.

Halim,A., Budi., S.(2016), Faktor Yang Berbubungan Dengan Kejadian TB Paru di public healt centreSempor I Kebumen. Fakultas Kedokteran dan Ilmu Kesehatan Universitas Jambi.

Indrawati. (2017). Analisis Faktor Yang Berbubungan dengan Kejadian TB Paru ?BTA (+) di Kabupaten Wonosobo. Tesis. Program Pascasarjana Universitas Diponegoro. Semarang.

Isgiyanto, A., (2009). Teknik Pengambilan Sampel Pada Penelitian Non-Eksperimental : Mitra Cendikia Press, Jogyakarta.

Ismiyanti.,A., Prasasti I., Astutik., E. (2018). Hubungan Lingkungan Fisik Ruang Tidur dan Keluarga Dengan Kasus Baru Tuberkulosis Paru BTA Positif di Wilayah Kerja public healt centreSonggon Banyuwangi. Fakultas Kesehatan Masyarakat. Universitas Airlangga.

Jusuf, W. M. (2010). Buku Ajar Ilmu Penyakit Paru. Jakarta: Departemen Ilmu Penyakit Paru FK Unair-RSUD Dr. Soetomo.

Masdalena, (2012). Pengarub Higiene dan Sanitasi Lingkungan terhadap Kejadian Penyakit Tuberkulosis Paru pada Warga Binaan Pemasyarakatan di Blok D Rumah Tahanan Negara Kelas I Medan. Tesis.Fakultas Kesehatan Masyarakat Universitas Sumatera Utara.

Masriadi., (2017). Epidemiologi Penyakit Menular. Depok: RajaGrafindo Persada

Mukono, H. J., (2002). Epidemiologi Lingkungan. Surabaya: Airlangga University Press.

Muslimah, L. (2018). Keadaan Lingkungan Fisik dan Dampaknya Pada Keberadaan Mycobacterium Tuberculosis :Studi di Wilayah Kerja public bealt centrePerak. Timur Surabaya. Fakultas Kesehatan Masyarakat. Universitas Airlangga

Lapau,B., \& Birwin.A, (2017). Prinsip dan Metode Epidemiologi :Penerbit Kencana

Notoatmodjo, S, (2012). Promosi Kesehatan dan Perilaku Kesehatan. Jakarta Rineka Cipta.

Oktavia, S., (2016 ). Analisis Faktor Risiko Kejadian TB Paru Di Wilayah Kerja

public bealt centreKertapati Palembang. Fakultas Kesehatan Masyarakat Universitas Sriwijaya.

Padmanesan, Agung. (2015). Merokok dan Tuberkulosis. Jurnal Tuberkulosis Indonesia Volume 3. No 2. Jakarta

Pangalo.,M.,Asrifuddin.,Kapantow.,N.(2018). Faktor Risiko Kejadian Tuberkulosis Paru Di public bealt centreEnemawira Kecamatan Tabukan Utara Kabupaten Kepulauan Sangibe. Fakultas Kesehatan Masyarakat Universitas Sam Ratulangi.

Rachmawati.,(2007).Hubungan Antara Karakteristik Lingkungan Rumah dengan Kejadian Tuberkulosis (TB) Pada Anak Di Kecamatan Paseh Kabupaten Subang, Fakultas Ilmu Keperawatan. Bandung: Universitas Padjadjaran

Rusnoto. (2008). Faktor-Faktor Yang Berhubungan Dengan Kejadian TB Paru Pada Usia Dewasa( Studi kasus di Balai Pencegahan Dan Pengobatan Penyakit Paru Pati ). Jurnal Epidemiologi, Universitas Diponegoro, Semarang.

Sastroasmoro, S., (2013). Dasar - dasar Metodologi Penelitian Klinis. Jakarta: Sagung Seto.

Setiyadi.,D., Adi., S. ( 2018 ). Pengetahuan, Praktik Pencegahan Dan kondisi Rumah Pada Kontak 
Serumah Dengan Penderita TB Paru Di Kabupaten Demak. Fakultas Kesehatan Masyarakat.Universitas Diponegoro.

Siahaan, Arian.(2015). Kejadian Tuberkulosis Pada Anggota Keluarga Yang Tinggal Serumah dengan Penderita TB Paru BTA Positif di Kota Pematang Siantar Tahun 2015. Tesis FKM USU

Susila \& Suyanto, (2015). Metodologi Penelitian Case Control :Bossscript

Suwondo. (2014). Hubungan Antara Riwayat Kontak, Kelembaban, Pencahayaan, Dan Kepadatan Hunian Dengan Kejadian Tuberkulosis Paru Pada Anak Di Kabupaten Sukoharjo.

Soemirat, J.S., (2009). Kesehatan Lingkungan. Yogyakarta: Gadjah Mada University Press.

Sinaga., BYM., (2014). Efek dari Merokok dan Konsumsi Alkobol pada TB Paru di Kalangan Etnis Batak di Medan, Imdonesia. Fakultas Kedokteran Sumatera Utara, Medan, Indonesia.

Suarni, H.,2016. Faktor Risiko yang Berbubungan dengan Kejadian Penderita Penyakit TB Paru BTA Positif di KecamatanPancoran Mas Kota Depok. Skripsi.Depok: FKM UI.

Suyono \& Budiman, (2010). Ilmu Kesehatan Masyarakat Dalam Konteks Kesehatan Lingkungan. Jakarta: EGC.

Tjiptoherijanto, P. \&Soesetyo, B., 2011.EkonomiKesehatan. Jakarta: RinekaCipta.

Widoyono,(2008). Penyakit Tropis Epidemiologi, Penularan, Pencegahan \& Pemberantasannya. Jakarta: Erlangga.

WHO, (2011).Global Tuberculosis Control. Switzerland: World Health Organization Library Cataloguing in Publication Data.

— (2014).Global Tuberculosis Report 2014. Switzerland: World Health Organization Library Cataloguing in Publication Data.

Wulandari, A. (2015). Faktor Risiko dan Potensi Penularan Tuberkulosis Paru di Kabupaten Kendal, Jawa Tengah. Jurnal Kesehatan Lingkungan Indonesia Vol. 14, No. 1Tahun 2015. JaKarta

Yigibalom., Sulistiyani., Nurjazuli.( 2018 ). Faktor Risiko Kebiasaan Tinggal Di Rumah Etnis dan Membuang Dabak Sembarang Pada Kejadian TB Paru Di kabupaten Jaya wijaya papua. Fakultas Kesehatan Masyarakat.Universitas Diponegoro. 